\title{
Shearing Date Affects Growth and Quality of Fraser Fir Christmas Trees
}

\author{
L. Eric Hinesley and Scott A. Derby \\ Department of Horticultural Science, North Carolina State University, Raleigh, \\ NC 27695-7609
}

\section{Additional index words. Abies fraseri, growth, USDA grade, retail value}

\begin{abstract}
Fraser fir [Abies fraseri (Pursh) Poir.] Christmas trees were sheared once annually over 4 years on dates ranging from July to March. Shearing reduced total tree growth. Trees sheared in July and August had the highest quality and retail value. Early shearing (July and August) yielded fewer leaders, longer leaders, and 35\% to $66 \%$ more internodal branches on the leader, compared to later shearing (September through March). Early shearing also yielded more second-order laterals, followed by greater elongation of those laterals. Shearing late into the fall yielded progressively fewer branches, with the minimum in October. Shearing in March gave a little better results than October, but neither date was as good as July or August. In one experiment, two types of residual tip buds (bubble and whisker) were compared as future leaders. Differences in length and straightness of leaders derived from whisker and bubble buds were considered negligible in commercial shearing practice. The ratio of adaxial and abaxial buds on the proximal portion of the leader was about 1:1, and showed little change with shearing date. Distance from the base of the leader to the first abaxial branch also showed little variation among shearing dates.
\end{abstract}

Fraser fir [Abies fraseri (Pursh) Poir.] is a valuable Christmas tree species indigenous to isolated mountain tops in western North Carolina, eastern Tennessee, and southwestern Virginia. It produces one flush of shoot growth between early May and early July. Fraser fir Christmas trees acquire a dense, conical shape as a result of annual pruning or shearing. An important issue is when to shear for best growth and quality because shearing practices vary among species and genera. Eastern white pine (Pinus strobus L.) has is a narrow window of time for successful shearing (Whitfield, 1977), whereas virginia pine produces multiple flushes of shoot growth and requires shearing at least twice during the growing season (Brown, 1979, Davis, 1972). Abies species can be sheared almost year round, though not during active shoot elongation, but middle to late summer appears most ideal (Douglass, 1983; Powell, 1982, Whitfield, 1977).

When fraser fir leaders are clipped during shearing, the cut is made $\approx 0.5$ to $1.0 \mathrm{~cm}$ above a bud that will produce next year's leader. There is some debate about the type of bud to select. Whisker buds (Fig. 1) are subtended by small linear leaves (needles) 2 to $3 \mathrm{~mm}$ long, and can be relatively large. Bubble buds or sessile buds (Fig. 1) are smaller, and subtended by a single linear leaf of normal size ( 20 to $25 \mathrm{~mm}$ ). The

Received for publication 7 Apr. 2003. Accepted for publication 11 Sept. 2003. We thank Jeff Owen (N.C. Coop. Extension Serv.) for help in installation; Don Tucker (Ashe Co., N.C. ) who kindly allowed us to use his Christmas trees and helped in establishment and shearing; Jerry Washington (Alleghany County Coop. Extension Serv., N.C. ) for assistance in establishment and shearing; Ron Farmer (Sparta, N.C.) for grading trees; and the staff of the Upper Mt. Res. Sta. (Laurel Springs, N.C.) for maintaining the experiment on that station. This research was funded in part by the North Carolina Agricultural Research Service, Raleigh. bud that produces the new leader quickly turns upward (orthotropic) as it gains dominance, but the morphological lower and upper side remain evident for several years near the base of the new leader.

Branches have fewer buds on the abaxial (lower) side, compared to the adaxial (upper), and bud density increases toward the distal end (Powell, 1982). When the new leader straightens, this configuration can lead to defects such as uneven crown density, or gaps. There is great variability among trees with respect to internodal budset and bud distribution. The worst scenario is for an emerging leader to have no buds on the lower side, or to have a large space, e.g., 15 to $20 \mathrm{~cm}$, before the occurrence of the first bud. Consequently, when the shoot becomes orthotropic, there might be a noticeable gap or open area on the abaxial side, which can reduce tree quality and value [U.S. Department of Agriculture (USDA), 1989).

The objective of this research was to determine the effect of various shearing dates on growth and quality of fraser fir Christmas trees, and determine differences, if any, between bud types as future leaders.

\section{Materials and Methods}

Experiment 1 (shearing date $\times$ bud type). From 1998 to 2000, shearing treatments were applied in a field of fraser fir Christmas trees (initial height $=1.3 \mathrm{~m}, 4$ years in the field) near Laurel Springs in the upper mountain region of North Carolina (lat. 36 $24^{\prime} \mathrm{N}$, long. 81 ${ }^{\circ} 18^{\prime}$ W). Soil was a Fannin loam (Typic hapludult, fine-loamy, mesic; elevation $\approx 1150 \mathrm{~m}$ ). Each year, trees were sheared on five dates: early July, August, September, October, and March. Budbreak occurs in early May, and shoot elongation ends by early July. Two types of buds were tested as future leaders: whisker, and bubble (Fig. 1). Owing to a delayed start in 1998, the July treatments were imposed in August. All other treatments were according to schedule.

The experiment was a randomized complete block with 50 blocks, and treatments were combined factorially (five dates $\times$ two bud types). Each block consisted of 10 contiguous trees, with treatments assigned randomly. Small trees were initially excluded as were trees with other problems, e.g., off-color. A few trees were later omitted owing to damage from birds, insects, disease, or nutritional problems.

In 1999, 2000, and 2001 the following variables were measured: 1) length of longest leader, 2) number of leaders, and 3) length of best leader after shearing to an appropriate bud. A leader (value $=1$ ) was counted as any vertical (orthotropic) shoot emerging near the top of an internode, or a dominant branch that was clearly oriented as a leader. Leaders display radial symmetry of needles and buds. Branches, which have a decussate (two-ranked) arrangement of needles, received a value of 0 in leader counts and 1 in branch counts. Shoots intermediate between leaders and branches were assigned values of 0.5 in leader counts and 0.5 in branch counts.

In 1999, leader offset (horizontal distance from the tip of the leader to the vertical axis of the tree) was measured, but measurements were discontinued when treatment differences from 1999 proved negligible.

In 2000, branch counts were obtained for the adaxial (upper) and abaxial (lower) side of the 1999 internode (leader), as well as the distance to the first branch on the abaxial side. Similarly, branches were counted on the 2000 leader internode in Fall 2001. Because distance to the first

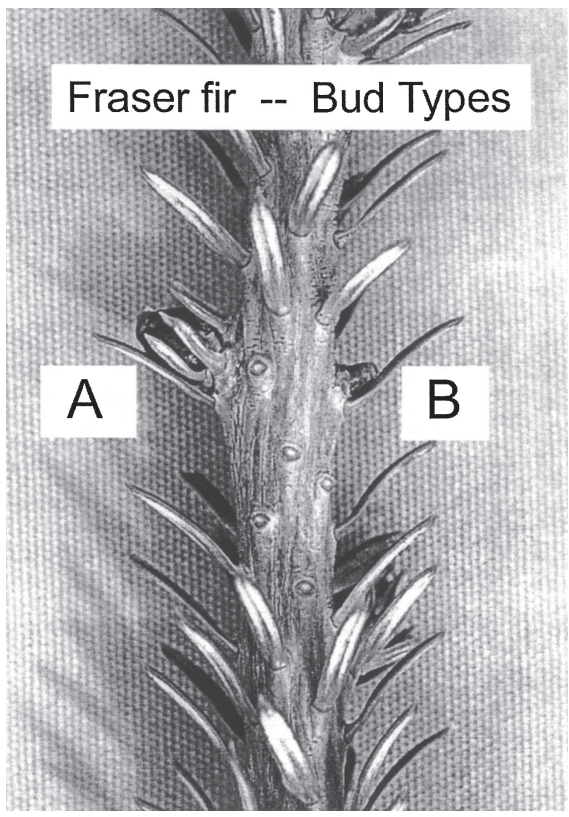

Fig 1. Types of buds selected for the future leader on terminals (primary axis) of fraser fir Christmas trees: (A) whisker bud and (B) bubble bud. A whisker bud has small linear leaves (needles) surrounding its base, whereas a bubble bud is typically smaller than a whisker bud, and is subtended by a single linear leaf of normal size. Several linear leaves (needles) were removed from the stem to improve viewing. 
Table 1. Leader number and length on fraser fir Christmas trees in response to 1) shearing date and 2) type of bud selected as the future leader (two experiments, Laurel Springs, N.C.).

\begin{tabular}{|c|c|c|c|c|c|c|c|c|}
\hline \multirow{2}{*}{ Treatment } & \multirow{2}{*}{$\begin{array}{l}\text { Trees } \\
\text { (no.) }\end{array}$} & \multicolumn{7}{|c|}{ Year } \\
\hline & & \multicolumn{3}{|c|}{1999} & \multicolumn{2}{|c|}{2000} & \multicolumn{2}{|c|}{2001} \\
\hline \multicolumn{9}{|l|}{ Expt. 1 (Tucker Plantation) } \\
\hline July & 90 & 2.2 & 36 & 1.9 & 2.0 & 54 & 2.7 & 54 \\
\hline August & 93 & 2.3 & 42 & 1.1 & 2.4 & 50 & 3.0 & 51 \\
\hline September & 94 & 2.6 & 40 & 1.3 & 2.5 & 43 & 3.1 & 49 \\
\hline \multicolumn{9}{|l|}{ Bud type } \\
\hline Bubble & 225 & --- & 39 & 1.3 & --- & 45.8 & 3.2 & 49 \\
\hline Whisker & 250 & --- & 41 & 1.6 & --- & 46.5 & 2.9 & 52 \\
\hline Date & & $* *$ & $* *$ & $*$ & $* *$ & $* *$ & $* *$ & $* *$ \\
\hline July vs. August & & NS & ** & ** & ** & ** & NS & ** \\
\hline August vs. October & & $* *$ & NS & $*$ & $* *$ & $* *$ & $*$ & $* *$ \\
\hline October vs. March & & $* *$ & NS & NS & NS & NS & $* *$ & $* *$ \\
\hline$R^{2}$ & & 0.14 & 0.23 & 0.16 & 0.14 & 0.36 & 0.18 & 0.21 \\
\hline \multicolumn{9}{|c|}{ Expt. 2 (Upper Mountain Research Station) } \\
\hline \multicolumn{9}{|c|}{ Shearing date } \\
\hline Control & 49 & --- & --- & 0.8 & 1.5 & 51 & 1.2 & 67 \\
\hline July & 35 & --- & --- & 1.4 & 2.0 & 57 & 2.5 & 56 \\
\hline August & 40 & --- & --- & 1.2 & 2.2 & 45 & 2.4 & 50 \\
\hline October & 35 & --- & --- & 1.3 & 2.9 & 43 & 2.7 & 50 \\
\hline March & 44 & --- & --- & 1.0 & 2.3 & 45 & 2.6 & 52 \\
\hline \multicolumn{9}{|l|}{ Significance } \\
\hline Date & & --- & --- & NS & $* *$ & ** & $* *$ & ** \\
\hline Control vs. sheared & & --- & --- & --- & $* *$ & * & $* *$ & ** \\
\hline July vs. August & & --- & --- & --- & NS & $* *$ & NS & $* *$ \\
\hline August vs October & & --- & --- & -- & ** & NS & NS & NS \\
\hline October vs March & & --- & --- & -- & $*$ & NS & NS & NS \\
\hline
\end{tabular}

${ }^{2}$ Offset $=$ horizontal displacement of leader apex from vertical axis of tree.

Ns,****Nonsignificant or significant at $P<0.05$ or 0.01 , respectively; $R^{2}=$ coefficient of determination.

branch on the 1999 internode was unaffected by treatments, measurements of that variable were discontinued. In Fall 2001, an experienced retail marketer of Christmas trees graded each tree (USDA, 1989), as follows: cull $=0$, grade $2=1$, grade $1=2$, and premium $=3$. Each tree was also assigned a retail value (\$).

Experiment 2 (shearing date). This experiment evaluated shearing dates similar to Expt. 1 , but with no distinction of bud types. The experiment was initiated in a block of fraser fir ( 1 to $1.3 \mathrm{~m}$ tall, 3 years in the field) Christmas trees on the Upper Mountain Research Station, Laurel Springs, N.C. Soil was a Watauga loam (Typic hapludult, fine-loamy, mesic; elevation $\approx 1,000 \mathrm{~m}$ ). Treatments included a control (no shearing) and four shearing dates: early July, late August, late September to mid-October, and March. The experimental design was a randomized complete block with 50 blocks. Treatments were assigned randomly to single trees within each five-tree block.

All trees were sheared according to standard practice in July 1998. Before shearing in July 1999, a dominant branch was selected and tagged at the top of the 1998 leader internode. Between July 1999 and March 2000, leaders were cut to $\approx 30 \mathrm{~cm}$, excluding controls, and branches in the top whorl were shortened to about half this length. Below the top whorl, the distal tip was pruned from all major branches in the tree crown. A few trees with leaders shorter than $30 \mathrm{~cm}$ were not sheared in 1999, and were eventually excluded from the analysis.

Leaders. Before shearing, the following variables were measured: 1) number of leaders on the primary axis or trunk $(1999,2000,2001)$, 2) length of the longest leader $(1999,2000$, 2001),3) horizontal offset (centimeters) of the leader apex from vertical (1999), and 4) number and lengths of first-order lateral branches on the prior-year leader (2000 and 2001). In 2000, the abaxial and adaxial branches on the 1999 leader were counted separately, but no treatment effect was found on branch distribution. Therefore, only totals were counted on the 2000 leader. Lengths of first-order lateral branches on the prior-year internode were measured in Fall 2000 for the control and August and March shearing. Measurements in Fall 2001 included all treatments.

Large branches. Before shearing after the 2000 and 2001 growing seasons, several measurements were made in each tree on the first-order lateral branch chosen originally in the upper crown: 1) number of second-order lateral branches produced on the internode of the previous year, and 2) length of the two longest branches on the same internode. For nonsheared trees (controls), the length of the terminal shoot (primary axis) was also measured on each branch.
Tree grade and quality. On 31 Jan. 2002, three people rated independently each tree in two ways: 1) the entire tree and 2) the portion of the tree above the 1999 whorl. A rating of 5 meant that the tree had excellent density and branch symmetry; the lowest rating (1) signified sparse density and/or uneven branch distribution. With this system, a nonsheared tree rated no higher than 3 (medium density).

Statistical analysis. In both experiments, data were analyzed with general linear model (GLM) procedures (SAS Institute, Inc., 1990). Linear contrasts ( $1 \mathrm{df}$ ) were used to make preselected treatment comparisons, including the average tree grade and quality for early shearing (July and August, combined) versus later shearing (September and later, combined).

\section{Results}

In general, early shearing (July) yielded about two leaders per tree, compared to three for trees sheared in late fall (Table 1). However, in 2 of 3 years, the number of leaders resulting from shearing in March was similar to that of July. Among shearing treatments, July usually yielded the longest leaders (Table 1). The one exception occurred in July 1999 (Table 1, Expt. 1), probably because leaders were not fully elongated when sheared.

Leader offset from vertical averaged $0.8 \mathrm{~cm}$ 
in nonsheared trees, and 1 to $2 \mathrm{~cm}$ for sheared trees (Table 1). With one exception (Expt. 1, July 1999), final offset was similar among shearing treatments. Differences were likely too small to influence tree quality and value. The difference between bubble and whisker buds was also insignificant (Table 1).

In both experiments, July shearing yielded the most internodal branches on the residual leader (Table 2). Later shearing yielded progressively fewer internodal branches, with the minimum in October (Table 2). Trees sheared in July (Expt. 1) had 39\% to 66\% more internodal branches, compared to October. Nonsheared trees averaged 20 internodal branches on the lower $32 \mathrm{~cm}$ of the 1999 leader-similar to trees sheared in July and August (Table 2, Expt. 2).

Shearing increased the length of internodal branches on the lower portion of the leader (Table 2, Expt. 2). In 1999, these branches were at least $50 \%$ longer than the controls; in 2000 , the difference was $69 \%$ to $93 \%$.

Shearing date had minimal absolute effect on the distribution of abaxial and adaxial branches (Table 2), with about half the buds on each side. Some differences, although significant, were too small to be of practical consequence. In addition, distance to the first abaxial bud showed no clear pattern related to shearing date (Table 2), and differences were regarded as too small to have practical consequence.
Density of first-order laterals on leaders was $\approx 0.6$ branches/cm for early shearing (July and August), and decreased to its minimum (0.4) for October shearing (Table 2, Expt. 1, 1999). The pattern was similar for the leader in 2000 except that the earliest shearing date (July) yielded significantly greater branch density than August. In Expt. 2, internodal branch density was 0.63 to 0.67 branches/cm for July shearing, compared to $\approx 0.5$ for October and March. Respective values for 2000 were 0.55 to 0.60 , and 0.4 .

In Expt. 1 (TuckerFarm, average tree height $\approx 2 \mathrm{~m}$ ), whisker buds provided a slightly taller tree than bubble buds (Table 3 ), but the means for both bud types were within the limits for a single 1-ft $(0.3-\mathrm{m})$ commercial height class. Orthogonal comparisons showed that average tree grade and retail value for July and August shearing (1.8 and \$38.64, respectively) was significantly greater than the combined average (1.6 and \$36.16, respectively) for trees sheared in September, October, and March (Table 3, Expt. 1). Bud type had negligible effect on tree grade or retail value. In Expt. 2 (Research Station), overall tree grade was similar among shearing treatments, probably because the experiment was initiated at midrotation (Table 3). However, ratings of the upper crown were significantly higher for trees sheared in July or August.

In 2000 (Table 4, Expt. 2), the number of second-order lateral branches was $\approx 50 \%$ greater for nonsheared trees (21.6), compared to the best shearing treatment $($ July $=10.4)$. In 2001, the difference dropped to $31 \%$. Early shearing (July and August 2000) yielded significantly more laterals than later shearing (October and March), with a 35\% difference between the best and worst treatments. Similarly in 2001, July shearing yielded the highest number of second-order laterals.

In addition to the number of second-order laterals, shearing also affected the spatial density of these branches. Nonsheared trees had the greatest branch density at 0.82 to 0.87 branches/cm for 2000 and 2001, respectively (Table 4, Expt. 2). Trees sheared in July and August (year 2000) had about $43 \%$ greater density than October or March (0.64 to 0.68 vs. 0.46 to 0.48$)$. In 2001 , the best shearing treatment (July) had 45\% lower branch density than controls ( 0.48 vs. 0.87 ), but $60 \%$ higher density than trees sheared in March (0.48 vs. 0.30).

The length of second-order lateral branches was also affected by shearing date (Table 4, Expt. 2). The two longest second-order laterals in the control averaged $16.6 \mathrm{~cm}$ in 2000 . The longest laterals occurred in the July shearing, averaging $19.9 \mathrm{~cm}$; the shortest, $12.2 \mathrm{~cm}$, was for the October shearing-almost $40 \%$ less than July. Average length was $14.3 \mathrm{~cm}$ for trees sheared in March-28\% less than July. In 2001, July shearing again yielded the longest branch lengths.

Table 2. Internodal branches on leaders of fraser fir (1999 and 2000) in response to 1) shearing date and 2) type of bud selected as the future leader (two experiments, Laurel Springs, N.C.).

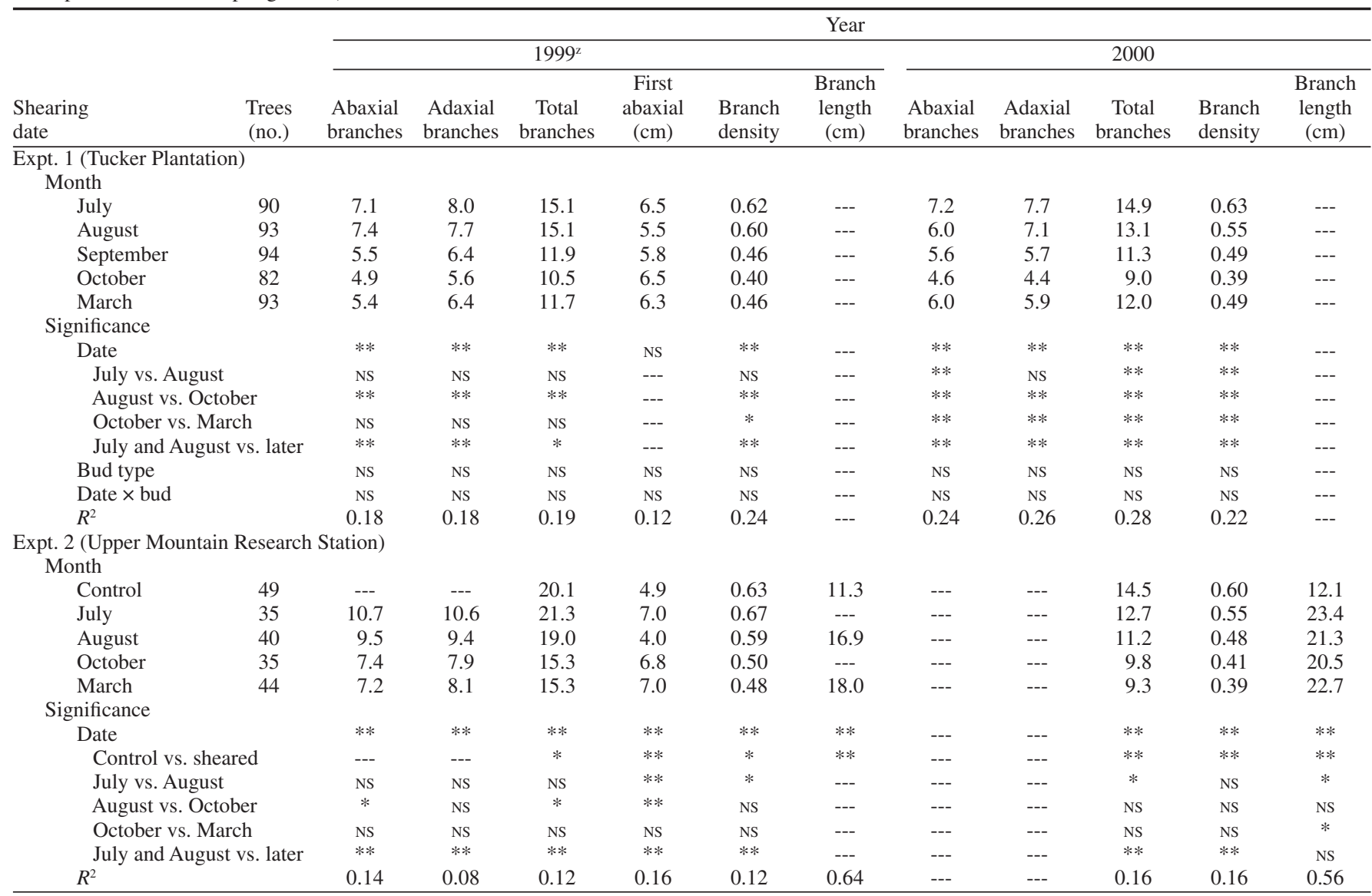

${ }^{2}$ First abaxial $=$ distance from base of leader to first abaxial branch, density $=$ no. branches per centimeter of leader.

Ns,,*** Nonsignificant or significant at $P<0.05$ or 0.01 , respectively. $R^{2}=$ coefficient of determination. 
Table 3. Height, grade, and retail value of fraser fir Christmas trees as affected by shearing date and type of bud selected for the future leader (two experiments, Laurel Springs, N.C.).

\begin{tabular}{|c|c|c|c|c|c|}
\hline $\begin{array}{l}\text { Shearing } \\
\text { date }\end{array}$ & $\begin{array}{l}\text { Trees } \\
\text { (no.) }\end{array}$ & $\begin{array}{l}\mathrm{Ht} \\
(\mathrm{m})\end{array}$ & $\begin{array}{c}\text { Tree } \\
\text { grade }^{z}\end{array}$ & $\begin{array}{c}\text { Top } \\
\text { rating }^{2}\end{array}$ & $\begin{array}{c}\text { Retail } \\
\text { value } \\
(\$)\end{array}$ \\
\hline \multicolumn{6}{|c|}{ Expt. 1 (Tucker Plantation) } \\
\hline \multicolumn{6}{|c|}{ Month } \\
\hline July & 92 & 1.95 & 1.79 & --- & 38.78 \\
\hline August & 93 & 1.89 & 1.82 & --- & 38.50 \\
\hline September & 94 & 1.89 & 1.63 & --- & 36.65 \\
\hline October & 83 & 1.89 & 1.64 & --- & 35.54 \\
\hline March & 93 & 1.92 & 1.62 & --- & 36.28 \\
\hline \multicolumn{6}{|l|}{ Bud type } \\
\hline Bubble & 225 & 1.88 & --- & --- & --- \\
\hline Whisker & 230 & 1.93 & --- & --- & --- \\
\hline \multicolumn{6}{|l|}{ Significance } \\
\hline Date & & NS & $*$ & --- & NS \\
\hline July vs. A & & --- & NS & --- & NS \\
\hline August vs & & --- & NS & --- & NS \\
\hline October v: & & --- & NS & --- & NS \\
\hline July and A & ater & --- & $* *$ & --- & $* *$ \\
\hline Bud type & & $* *$ & NS & --- & NS \\
\hline Date $\times$ bud & & NS & NS & --- & NS \\
\hline$R^{2}$ & & 0.25 & 0.17 & --- & 0.18 \\
\hline \multicolumn{6}{|c|}{ Expt. 2 (Upper Mountain Research Station) } \\
\hline \multicolumn{6}{|c|}{ Month } \\
\hline Control & 50 & --- & 2.20 & 2.15 & --- \\
\hline July & 50 & --- & 3.54 & 3.55 & --- \\
\hline August & 52 & --- & 3.75 & 3.61 & --- \\
\hline October & 50 & --- & 3.37 & 3.11 & --- \\
\hline March & 54 & --- & 3.39 & 3.01 & --- \\
\hline \multicolumn{6}{|l|}{ Significance } \\
\hline Date & & --- & $* *$ & $* *$ & --- \\
\hline Control vs & & --- & $* *$ & $* *$ & --- \\
\hline July vs. A & & --- & NS & NS & --- \\
\hline Aug. vs. O & & --- & $* *$ & $* *$ & --- \\
\hline October v & & --- & NS & NS & --- \\
\hline July and A & ater & --- & $* *$ & $* *$ & --- \\
\hline$R^{2}$ & & --- & 0.41 & 0.34 & -- \\
\hline
\end{tabular}

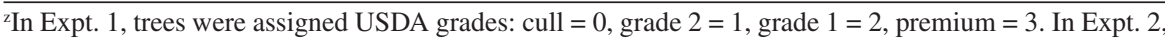
all ratings were based on a subjective scale of 1 (worst) to 5 (best).

ss, ${ }^{*}, *$ Nonsignificant, or significant at $P<0.05$ or $0.01, R^{2}=$ coefficient of determination.

\section{Discussion}

Results were consistent between experiments. In addition, some treatment differences were statistically significant, but too small to have commercial importance. For example, natural leaders are often twice the length of the residual leader after shearing. Thus, if two treatments differ by $2 \mathrm{~cm}$ (say $5 \%$ of maximum leader length), the difference, although perhaps statistically significant, would be of no practical consequence because $50 \%$ or more of the distal portion of the leader is commonly removed during shearing. Conversely, treatments that increase branch elongation (vigor) influence crown density by filling the crown faster, and reaching the shearing line quicker.

The maximum benefit of shearing occurs if it increases the number of internodal buds on the lower (proximal) 25 to $30 \mathrm{~cm}$ of the leader, the portion still present after shearing. The same generalization applies to the number of second- and third-order lateral branches. The cumulative effect of annually compounding a small increase in buds could enhance crown density and appearance over a rotation. Trees sheared in July had branch density similar to the control (Table 2, Expt. 2), and density decreased with progressively later shearing. In contrast, internodal branch length on leaders was $50 \%$ to $93 \%$ greater for sheared trees, indicating beneficial compensatory growth.

Shearing in the fall or late winter reduced internodal branch density (Tables 2 and 4 ). The fact that nonsheared trees had up to 2 times more second-order laterals merely reflected that those branches were not sheared, and were thus longer than sheared shoots. Bud density is highest on the distal half of the twig (Powell, 1982), so retaining that portion (no shearing) of the twig preserves the highest potential branch density, assuming no compensatory effect in the proximal part of sheared branches. The longest second-order lateral branches occurred in trees sheared in July.

Failure to realize greater treatment differences in grade and retail value likely resulted from shearing to a fixed leader length, which caused final tree height to be similar (Table 3). Tree value is determined primarily by height; secondarily, by grade (Arnold et al., 1995). An alternative system is 'flexible shearing' where final length of sheared leaders is longer on trees with greater internodal bud density. Annually retaining a longer leader for several years can put a tree into a taller height class at the end of the rotation, or allow for a target height in less time. An additional $0.3-\mathrm{m}$ in height can increase retail value by $\$ 10.00$ to $\$ 15.00$ for a 2-m tree.

Past research with fraser fir correlated various attributes of trees with tree grade (Arnold et at., 1994a; Hockman et al., 1990). Height and crown density at mid-rotation are two of the best predictors of final grade and retail value (Arnold et al., 1994). In our studies, tree growth and quality seemed to be influenced much or more by inter-tree variation than by shearing date. All treatments, from earliest to latest, had some high quality trees; similarly, every treatment had some trees of low grade. Traits of fraser fir vary strongly among individuals and families (Arnold et al., 1994a, 1994b; Jett Table 4. Production of second-order lateral branches on fraser fir Christmas trees in response to shearing date (Expt. 2, Upper Mountain Research Station).

\begin{tabular}{|c|c|c|c|c|c|c|c|}
\hline \multirow[b]{3}{*}{$\begin{array}{l}\text { Shearing } \\
\text { date }\end{array}$} & \multirow[b]{3}{*}{$\begin{array}{l}\text { No. } \\
\text { trees }\end{array}$} & \multicolumn{6}{|c|}{ Year } \\
\hline & & \multicolumn{3}{|c|}{2000} & \multicolumn{3}{|c|}{2001} \\
\hline & & $\begin{array}{c}\text { No. } \\
\text { branches }\end{array}$ & $\begin{array}{l}\text { Length } \\
(\mathrm{cm})\end{array}$ & $\begin{array}{l}\text { Branch } \\
\text { density }^{z}\end{array}$ & $\begin{array}{c}\text { No. } \\
\text { branches }\end{array}$ & $\begin{array}{l}\text { Length } \\
(\mathrm{cm})\end{array}$ & $\begin{array}{l}\text { Branch } \\
\text { density }\end{array}$ \\
\hline Control & 49 & 21.6 & 16.6 & 0.82 & 13.5 & 15.7 & 0.87 \\
\hline Early July & 35 & 10.4 & 19.9 & 0.68 & 9.2 & 18.1 & 0.48 \\
\hline Late August & 40 & 9.3 & 13.2 & 0.64 & 6.3 & 16.7 & 0.39 \\
\hline Mid-October & 35 & 6.8 & 12.2 & 0.46 & 4.9 & 14.7 & 0.30 \\
\hline March & 44 & 7.9 & 14.3 & 0.48 & 4.8 & 15.4 & 0.30 \\
\hline \multicolumn{8}{|l|}{ Significance } \\
\hline Date & & $* *$ & $* *$ & $* *$ & $* *$ & $* *$ & $* *$ \\
\hline Control vs. sheared & & $* *$ & $* *$ & $* *$ & $* *$ & NS & $* *$ \\
\hline July vs. August & & NS & $* *$ & NS & $* *$ & NS & NS \\
\hline August vs. October & & $* *$ & NS & $* *$ & $* *$ & $* *$ & $* *$ \\
\hline October vs. March & & NS & $* *$ & NS & NS & NS & NS \\
\hline July and August vs. later & & $* *$ & $* *$ & $* *$ & $* *$ & $* *$ & $* *$ \\
\hline$R^{2}$ & 0.70 & 0.47 & 0.40 & 0.67 & 0.35 & 0.70 & \\
\hline
\end{tabular}

${ }^{\mathrm{Z}}$ Density $=$ no. of branches per centimeter of shoot length.

Ns, *,*** Nonsignificant or significant at $P<0.05$ or 0.01 , respectively; $R^{2}=$ coefficient of determination. 
et al., 1993; Li et al., 1988; Robinson and Thor; 1969, Thor and Barnett, 1974).

Absolute differences between whisker and bubble buds were small, so it appears unnecessary to prefer one bud type over the other. Shoot elongation for determinant species is related to bud size (Kozlowski, 1973; Little 1970). Consequently, with early shearing, the residual bud selected for next year's leader has ample time to develop and enlarge in late summer and fall.

Although there is a wide window of opportunity for shearing fraser fir, early shearing (July) yielded fewer leaders, straighter leaders, longer leaders, higher branch density, and longer first- and second-order laterals, compared to late shearing (October). These effects tend to increase quality and retail value. Often, however, trees are not sheared at the optimum time. Thus, if given a choice between shearing in late fall (October) or late winter (March), results herein suggest that March might be a better alternative.

\section{Literature Cited}

Arnold, R.J., F.E. Bridgwater, and J.B. Jett. 1994a. Single-and multiple-trait index selection efficiencies in fraser fir Christmas trees. Can. J. For. Res. 24:1487-1494.

Arnold, R.J., J.B. Jett, and W.T. Huxster. 1995. Relationship of U. S. Department of Agriculture grades to the value of fraser fir Christmas trees. HortScience 30:369-373.

Arnold, R.J., J.B. Jett, and S.E. McKeand. 1994b. Natural variation and genetic parameters in fraser fir for growth and Christmas tree traits. Can. J. For. Res. 24:1480-1486.

Brown, Jr., G.F. 1979. Shearing response of virginia pine. Amer. Christmas Tree J. 23(2):49-51.

Davis, T.S. 1972. Pruning techniques for producing southern pine Christmas trees. Ga. Agr. Expt. Sta. Res. Bul. 124.

Douglass, B.S. 1983. Noble fir shearing and fertilizer study. Christmas Tree Lookout 16(3):30-32, 34, $36,38,40$

Hockman, J.N., J.A. Burger, and D.W. Smith. 1990. Classification model to predict fraser fir Christmas tree grade. For. Sci. 36:45-53.

Jett, J.B., S.E. McKeand, Y. Liu, and W.T. Huxster. 1993. Seed source variation for height and crown traits of fraser fir Christmas trees. S. J. Appl.
For. 17:5-9.

Kozlowski, T.T. 1973. Predictability of shoot length from bud size in Pinus resinosa Ait. Can. J. For. Res. 3:34-38.

Li, B., J.B. Jett, and R.J. Weir. 1988. A preliminary study of geographic variation in fraser fir seedlings. S. J. Appl. For. 12:128-132.

Little, C.H.A. 1970. Apical dominance in long shoots of white pine (Pinus strobus). Can. J. Bot. 48:239-253

Powell, G.R. 1982. Shoot and bud development in balsam fir: Implications for pruning of Christmas trees. For. Chron. 58:168-172.

Robinson, J.F. and E. Thor. 1969. Natural variation in Abies of the southern Appalachians. For. Sci. 15:238-245.

SAS Institute, Inc. 1990. SAS/STAT user's guide. vol. 2. SAS Inst., Cary, N.C.

Thor, E. and P.E. Barnett. 1974. Taxonomy of Abies in the southern Appalachians: Variation in balsam monoterpenes and wood properties. For. Sci. 20:32-40.

U.S. Department of Agriculture. 1989. United States standards for grades of Christmas trees: Revised, effective 30 Oct. 1989.U.S. Dept.Agr.,Agr. Mktg. Serv., Wash., D.C. [FR Doc. 89-23043].

Whitfield,F.E. 1977. Growing Christmas trees in North Carolina. N.C. Agr. Ext. Serv. Bul. AG-95. 